\title{
A Review of Non-operative Treatments for Hepatocellular Carcinoma with Advanced Portal Vein Tumor Thrombus
}

\author{
Michihisa Moriguchi*, Mitsuhiro Furuta and Yoshito Itoh \\ Department of Molecular Gastroenterology and Hepatology, Kyoto Prefectural University of Medicine, Graduate School \\ of Medical Science, Kyoto, Japan
}

\begin{abstract}
Portal vein tumor thrombus (PVTT) frequently occurs with the progression of hepatocellular carcinoma (HCC) and is an important factor in determining the prognosis of HCC. In many cases of HCC with advanced PVTT, treatment is difficult because the tumor has considerable extension into the liver, and portal hypertension is a frequent complication. The standard therapy for unresectable HCC with advanced PVTT is sorafenib therapy in patients with good hepatic function. However, the outcomes of sorafenib therapy are not completely satisfactory, making the development of another therapy an urgent task. Therefore, this review aims to summarize non-operative treatments for HCC with advanced PVTT and discuss future perspectives based on those therapies, including therapies still being developed.

Citation of this article: Moriguchi M, Furuta M, Itoh Y. A review of non-operative treatments for hepatocellular carcinoma with advanced portal vein tumor thrombus. J Clin Transl Hepatol 2017;5(2):177-183. doi: 10.14218/JCTH. 2016.00075 .
\end{abstract}

\section{Introduction}

Hepatocellular carcinoma (HCC) is the world's fifth most common cancer and typically has a background of chronic hepatitis or cirrhosis. ${ }^{1}$ Portal vein tumor thrombus (PVTT) is frequently seen in the clinical course of HCC, occurring in $44-62.2 \%$ of cases according to past reports. ${ }^{2,3}$ In cases of HCC with PVTT, the tolerability of patients to therapy is low because their tumors are generally aggressive, their hepatic function is poor, and there is a high rate of complications from portal hypertension. The prognosis of HCC with advanced PVTT is extremely poor, resulting in a median survival time of 2-4 months without treatment. ${ }^{4-6}$ It was

Keywords: Hepatocellular carcinoma; Medical therapy management; Portal vein; Thrombus.

Abbreviations: 5-FU, 5-fluorouracil; CDDP, cisplatin; DEB, drug-eluting beads; HAIC, hepatic arterial infusion chemotherapy; HCC, hepatocellular carcinoma; IFN, interferon; LFP, low-dose 5-FU plus CDDP; MST, median survival time; PVTT, Portal vein tumor thrombus; RT, radiotherapy; TACE, transarterial chemoembolization; TARE, transarterial radioembolization.

Received: 30 December 2016; Revised: 21 February 2017; Accepted: 25 February 2017

*Correspondence to: Michihisa Moriguchi, Department of Molecular Gastroenterology and Hepatology, Kyoto Prefectural University of Medicine, Graduate School of Medical Science, 465 Kajii-cho, Kawaramachi-Hirokouji, Kamigyo-ku, Kyoto 602-8566, Japan. Tel: +81-75-251-5519, Fax: +81-75-0251-0710, E-mail: mmori@koto.kpu-m.ac.jp recently reported that PVTT extension in hepatitis $B$ virusrelated HCC involves genetic abnormalities of KDM6A, CUL9, FDG6, AKAP3, RNF139, etc. $^{7}$

Recently, a report was published stating that $V p 1-3$ (Japanese VP Staging Classification System) ${ }^{8,9}$ patients who underwent successful R0 or R1 resection had moderate outcomes, indicating the usefulness of surgical resection. ${ }^{10}$ However, non-operative treatment is the only available means in many cases in actual clinical practice because surgical resection is difficult in bilobar and multifocal cases and in patients with poor hepatic function.

Non-operative treatments include transarterial chemoembolization (TACE), transarterial radioembolization (TARE), hepatic arterial infusion chemotherapy (HAIC), sorafenib therapy, and radiotherapy (RT). Combinations of these treatments have also been attempted to improve outcomes. However, treatment outcomes for unresectable HCC with PVTT are not satisfactory. Particularly, management for advanced PVTT such as Vp3 (extension to the first-order branch)/Vp4 (extension to main trunk/contralateral branch) $\mathrm{HCC}$ with poor prognosis has room for discussion. Therefore, this review aims to discuss non-operative treatment for Vp3/Vp4 HCC, i.e. HCC with advanced PVTT, based on recent data.

\section{PVTT classifications}

Severity of PVTT is closely correlated with prognosis of HCC with PVTT. ${ }^{10}$ The Japanese VP Staging Classification System and the Eastern Hepatobiliary Classification (also known as Cheng's Classification $)^{11,12}$ can stratify HCC with PVTT.

In the Japanese VP Staging System, Vp4, Vp3, Vp2 and Vp1 are categorized as an extension to the main trunk/ contralateral branch, first-order branch, second-order branch and third-order branch, respectively (Fig. 1). The median survival times (MSTs) after diagnosis of PVTT stratified by severity has been reported as 2.67 years ( $95 \%$ CI $2.48-3.01$ ) for $\mathrm{Vp} 1$, 1.51 years $(95 \%$ CI $1.36-1.65)$ for $\mathrm{Vp} 2,0.78$ years $(95 \%$ CI $0.70-0.83$ ) for $\mathrm{Vp} 3$, and 0.50 years (95\% CI $0.45-0.56$ ) for $\mathrm{Vp} 4,{ }^{10}$ indicating a very poor prognosis for patients with $\mathrm{Vp} 3$ and Vp4. Vp3 and Vp4 are equivalent to types II/III (extension to the main trunk) and IV (extension to superior mesenteric vein) by Cheng's Classification, respectively (Fig. 1).

\section{TACE}

TACE was developed by Yamada et al. ${ }^{13}$ in 1977 and has since been widely used to treat unresectable HCC. TACE is based on 
Moriguchi M. et al: Non-operative treatments for HCC with PVTT

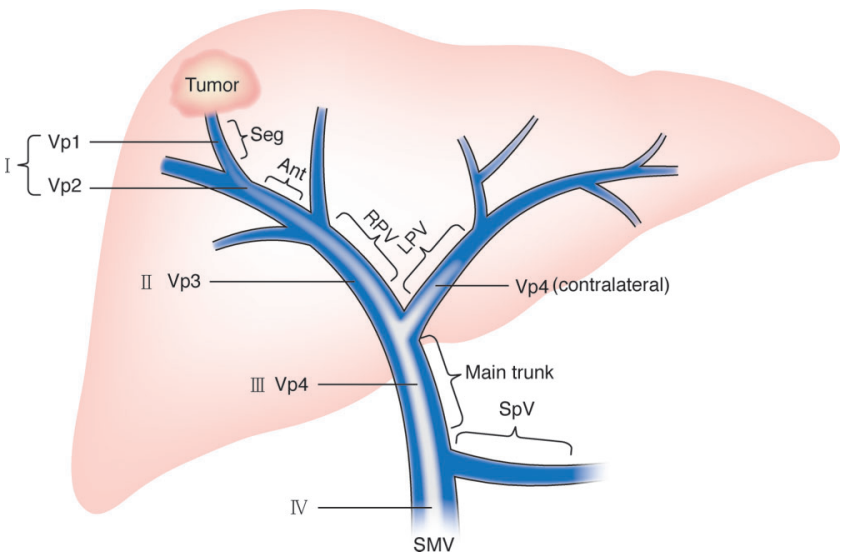

Fig. 1. Classification of hepatocellular carcinoma with portal vein tumor thrombus. Vp and Roman numerals express Japan's VP classification and Cheng's classification, respectively. $\mathrm{Vp} 4, \mathrm{Vp} 3, \mathrm{Vp} 2$ and $\mathrm{Vp} 1$ are categorized as an extension to the main trunk/contralateral branch, first-order branch, second-order branch, and third-order branch, respectively. Abbreviations: Ant, anterior branch; LHV left portal vein; RPV, right portal vein; Seg, segmental branch; SMV, superior mesenteric vein; SpV, splenic vein.

the following theories: The embolization of the hepatic artery leads to necrosis of the classical HCC fed by only the hepatic artery, on the other hand, the surrounding liver parenchyma would not result in infarction because it is fed predominantly by both the artery and the portal vein. ${ }^{13}$
A simultaneous combination of embolization with an anticancer agent is thought to enhance tumor necrosis through long-term retention of a high concentration of the agent in the tumor.

TACE for HCC with PVTT is likely contraindicated because of the theoretical concern for hepatic insufficiency caused by hepatic ischemia. However, recent studies have reported that TACE can be safely performed if the patient has good liver function and sufficiently developed collateral circulation around the occluded portal vein. Perioperative mortality of TACE and the incidence of TACE syndrome (post-embolization syndrome) have been reported to be below $1.2 \%$ and $28.9-94 \%$, respectively (Table 1 ). ${ }^{14,15}$

Niu et al. ${ }^{16}$ (Table 1 ) reported the usefulness of TACE for HCC with PVTT based on their prospective study. The MSTs of type II (Vp3) patients in the TACE and conservative arms was 11.0 and 1.43 months, respectively, and the MSTs of type III/IV (Vp4) patients in those arms was 7.1/4.0 and $1.3 / 1.0$ months, respectively, $(p<0.01)$ in the sub-analysis. Luo et al. ${ }^{17}$ (Table 1 ) reported that the TACE arm had a significantly longer survival time than the conservative treatment arm in their prospective study, and adverse events in the study could be managed sufficiently. They reported that in their sub-analysis, the MST of even the patients with major PVTT in the TACE arm was 5.4 months, significantly longer than the 3.4 months of the conservative arm $(p=0.002)$. Chung et al. ${ }^{14}$ reported the safety and usefulness of TACE for Vp4 HCC. The TACE group had a significantly longer survival

Table 1. Transarterial embolization for hepatocellular carcinoma with advanced portal vein tumor thrombus

\begin{tabular}{|c|c|c|c|c|}
\hline Author Ref & Treatment & Degree of PVTT; $n$ & $\begin{array}{l}\text { Median survival time; } \\
\text { months }\end{array}$ & Adverse event; n/total or \% \\
\hline Chung $^{14}$ & c-TACE & Main; 83 & Main; 5.6 & $\begin{array}{l}\text { Morbidity; } 28.9 \% \\
\text { Gastro-intestinal bleeding due to portal } \\
\text { hypertension; } 4.8 \% \\
\text { Bacteremia (SBP); } 6 \%(1.2 \%) \\
\text { Renal failure; } 1.2 \%\end{array}$ \\
\hline $\mathrm{Niu}^{16}$ & c-TACE & $\begin{array}{l}\text { Type II; } 52 \\
\text { Type III; } 42 \\
\text { Type IV; } 9\end{array}$ & $\begin{array}{l}\text { Type II; } 11.0 \\
\text { Type III; } 7.1 \\
\text { Type IV; } 4.0\end{array}$ & Unclear in detail \\
\hline Luo $^{17}$ & c-TACE & Major; 44 (all; 84) & Major; 5.4 & $\begin{array}{l}\text { Post-embolization syndrome }(79 / 84) \\
\text { Temporary liver decompensation }(29 / 84) \\
\text { One-month mortality } 1.2 \%\end{array}$ \\
\hline Kalva ${ }^{20}$ & DEB-TACE & $\begin{array}{l}\text { Advanced-stage; } 80 \\
\text { (with PVTT only } \\
12.5 \% \text { ) }\end{array}$ & & $\begin{array}{l}\text { Gr3 AST/ALT elevation } 15 \% \\
\text { Favorable tolerant and safe }\end{array}$ \\
\hline Sangro $^{21}$ & TARE & $\begin{array}{l}\text { Main; } 32(9.8 \%) \\
\text { Branch; } 44(13.5 \%)\end{array}$ & $\begin{array}{l}\text { Main; } 9.7 \\
\text { Branch; } 10.7\end{array}$ & $\begin{array}{l}\text { All-cause mortality at } 30 \text { and } 90 \text { days; } \\
0.6 \% \text { and } 6.8 \% \\
\text { Gr3 gastrointestinal ulceration; } 1.5 \% \\
\text { Gr3 or above Bil increase at month } 3 ; \\
5.8 \%\end{array}$ \\
\hline Memon $^{22}$ & TARE & $\begin{array}{l}\text { Main; } 29 \\
\text { lobar; } 34 \\
\text { (Child-Pugh A) }\end{array}$ & $\begin{array}{l}\text { Main; } 9.0 \\
\text { Lobar; } 15.7\end{array}$ & Unclear in detail \\
\hline Mazzaferro $^{23}$ & TARE & $\begin{array}{l}\text { Second-first } \\
\text { branch; } 29 \\
\text { Trunk-SMV; } 6\end{array}$ & $\begin{array}{l}\text { Second-first branch; } 17 \\
\text { Trunk-SMV; } 9\end{array}$ & $\begin{array}{l}\text { No significant difference in toxicity (PVTT } \\
\text { vs non-PVTT) }\end{array}$ \\
\hline
\end{tabular}

Abbreviations: ALT, alanine aminotransferase; AST, aspartate aminotransferase; Bil, bilirubin; C-TACE, conventional transarterial chemoembolization; DEB, drug eluting beads; Gr, grade; PVTT, portal vein tumor thrombus; SBP, spontaneous bacterial peritonitis; SMV, superior mesenteric vein; TARE, transarterial radioembolization. 
time than the supportive care group (MST: 5.6 months vs. 2.2 months, $p<0.001$ ). In particular, the cases classified as Child-Pugh A had an MST of 7.4 and 2.6 months in the TACE and supportive care groups, respectively, significantly longer in the TACE group $(p<0.001)$. There was no treatmentrelated death within 4 weeks after TACE, and the incidence of adverse events was $28.9 \%$. Although no significant difference was detected in the incidence of adverse events between the TACE and supportive care groups, complications such as gastrointestinal hemorrhage with secondary portal hypertension developed more frequently in the TACE group. ${ }^{14}$

From these results, it is likely that for Child-Pugh A cases and cases with well-developed collateral circulation around the occluded portal vein, TACE is an acceptable treatment for HCC with PVTT. However, the outcomes of TACE for Vp4 $\mathrm{HCC}$ are not fully satisfactory; therefore, it is important to compare those with the outcomes of other therapies.

Regarding embolic agents, those with a small particle diameter have been reported to have a higher antitumor effect and to cause less adverse events. ${ }^{18,19}$ Therefore, TACE using drug-eluting beads (DEB) is expected to be more effective than conventional TACE, in which embolization employs a gelatin sponge after arterial infusion of an emulsion of lipiodol and an anticancer agent. Although Kalva et al. ${ }^{20}$ (Table 1) reported the safety and usefulness of DEB-TACE for HCC with PVTT, there have been few definite reports on DEB-TACE for HCC with PVTT. This should be investigated in the future.

\section{TARE}

TARE is a treatment in which radioactive microspheres are injected into the tumor through its feeder artery, aiming for an embolic effect and radiotherapy. Contrary to TACE, complete embolization is not the technical endpoint of this treatment. For this reason, TARE has a weaker embolic effect and therefore can be more easily utilized for HCC with PVTT from the standpoint of hepatic function. A few reports have indicated the usefulness of yttrium-90 microspheres radiating beta rays for HCC with PVTT. Sangro et al. ${ }^{21}$ (Table 1 ) reported that TARE is a well-tolerated treatment, based on the severity and incidence of adverse events seen in TARE for main PVTT and branch PVTT (MSTs of 9.7 and 10.7 months, respectively). However, grade 3 or higher bilirubin levels were seen in $5.8 \%$ of patients within 3 months after the therapy, which could be due to hepatic dysfunction but were also likely due to the tumor progression or the exacerbation of the background liver disease such as cirrhosis. Memon et al. ${ }^{22}$ (Table 1 ) reported that the MST of the patients with Child-Pugh A disease and lobar PVTT/main PVTT who underwent TARE was 15.7/9 months. Mazzaferro et al. ${ }^{23}$ (Table 1) reported that in their phase II trial, the MST of patients with Child-Pugh A disease and first-branch/secondbranch PVTT was 17 months, and the MST of patients with portal trunk-superior mesenteric vein PVTT was 9 months, showing relatively good outcomes.

Regarding adverse events, TARE is generally well tolerated. The most frequent adverse event is post-embolization syndrome (malaise, fever, nausea, abdominal pain, etc), which is seen in approximately $20-55 \%$ of patients, but can usually be managed with conservative therapy. Other adverse events that have been reported include hepatic disorder, pneumonitis, cholecystitis, bile duct stenosis, hepatic abscess, and gastrointestinal ulceration as a result of radiation, but their incidence is low. ${ }^{24-26}$

\section{HAIC}

Theoretically, HAIC should be more effective than systemic chemotherapy and reduce adverse events because it allows for injection of a high concentration of an anticancer agent directly through the feeder artery. HAIC includes hepatic arterial infusion chemotherapy by means of a port-catheter system, in which an anticancer agent is repeatedly injected after implantation of the port-catheter system and a one-shot intra-arterial infusion of chemotherapy through a catheter inserted by the Seldinger technique. Regimens using cisplatin (CDDP) and 5-fluorouracil (5-FU) as key drugs, as well as regimens using 5-FU and interferon (IFN) as key drugs, have been used in many of the reported cases for which hepatic arterial infusion chemotherapy using a port-catheter system was employed. Using low-dose 5-FU plus CDDP (LFP) for Vp3/ Vp4 HCC, Ando et al. ${ }^{27}$ (Table 2) reported a response rate of $48 \%$ and an MST of 10.2 months. The most common adverse events were nausea and loss of appetite, and these were controllable with medical treatment. In $13 \%$ of the cases, treatment was discontinued because of deterioration of hepatic function, but the authors did not mention whether this deterioration was due to the tumor progression, the exacerbation of the background liver disease or technique/treatment. They did report that malfunction of the port-catheter system and/ or its implantation accounted for more than $20 \%$ of the complications. Obi et al. ${ }^{28}$ (Table 2 ) reported that the outcomes of IFN and 5-FU combination therapy for Vp3/Vp4 HCC were a response rate of $52.6 \%$, an MST of 6.9 months, and a 1 -year survival rate of $34 \%$. The majority of adverse events were negligible, while depression caused by IFN was the only adverse event of grade 3 or higher, which occurred in a patient for whom the treatment was discontinued. No catheter-related complications were found.

With regard to the one-shot intra-arterial infusion, we found some reports regarding intra-arterial CDDP infusion. Ikeda et al. ${ }^{29}$ (Table 2 ) reported that the outcomes of their phase II prospective trial of intra-arterial CDDP infusion for Vp3/Vp4 HCC were a response rate of $28 \%$ and an MST of 7.1 months. Regarding adverse events of grade 3 or higher, decreased blood cells and transient increases in transaminases were seen but required no special treatment. As stated above, HAIC for Vp3/Vp4 HCC is expected to be effective. However, there is insufficient evidence, as the number of cases in the reports is small.

In recent years, prospective trials have been conducted to verify the efficacy of HAIC as an add-on therapy for sorafenib therapy, the standard therapy for Barcelona clinic liver cancer stage $C$. In the phase III trial for verification of the efficacy of LFP as this add-on therapy, LFP was shown to be useful for patients with advanced PVTT, although the primary endpoint could not be satisfied. ${ }^{30}$ Meanwhile, a phase II trial showed the usefulness of one-shot intraarterial CDDP infusion as an add-on therapy for sorafenib therapy, although no significant difference for patients with PVTT was detected in the sub-analysis. ${ }^{31}$ A future prospective phase III trial to verify the usefulness of HAIC for Vp3/ Vp4 HCC is recommended. 
Moriguchi M. et al: Non-operative treatments for HCC with PVTT

Table 2. Hepatic arterial infusion chemotherapy for hepatocellular carcinoma with advanced portal vein tumor thrombus

\begin{tabular}{|c|c|c|c|c|c|}
\hline Author ${ }^{\text {Ref }}$ & Treatment & $\begin{array}{l}\text { Degree of } \\
\text { PVTT; n/total }\end{array}$ & $\begin{array}{l}\text { MST, TTP in } \\
\text { months }\end{array}$ & ORR, DCR; \% & Adverse event; \% or $\mathrm{n}$ \\
\hline Ando 27 & LFP & $\mathrm{Vp} 2 / 3 ; 14 / 34$ & 10.2 & $\begin{array}{l}\text { ORR; } 48 \\
\text { DCR; } 77\end{array}$ & $\begin{array}{l}\text { Any grade } \\
\text { nausea, appetite loss; } 34 \% \\
\text { Peptic ulcer; } 13 \% \\
\text { Deterioration of hepatic function; } 13 \% \\
\text { Catheter obstruction; } 10 \%\end{array}$ \\
\hline $\mathrm{Obi}^{28}$ & 5-FU with IFN s.c & $\begin{array}{l}\text { Vp3; } 88 \\
\text { Vp4; } 28\end{array}$ & 6.9 & $\begin{array}{l}\text { ORR; } 52.6 \\
\text { DCR; } 54.3\end{array}$ & $\begin{array}{l}\text { Gr3 } \\
\quad \text { Stomatitis; } 1 \\
\text { Depression; } 1\end{array}$ \\
\hline Ikeda $^{29}$ & cisplatin & $\begin{array}{l}\text { Vp3; } 6 \\
\text { Vp4; } 19\end{array}$ & 7.1 & $\begin{array}{l}\text { ORR; } 28 \\
\text { DCR; } 72\end{array}$ & $\begin{array}{l}\text { Gr3 } \\
\text { Leukocytopenia; } 5 \\
\text { Thrombocytopenia; } 4 \\
\text { AST elevation; } 10 \\
\text { ALT elevation; } 5\end{array}$ \\
\hline
\end{tabular}

Abbreviations: ALT, alanine aminotransferase; AST, aspartate aminotransferase; DCR, disease control rate; Gr, grade; HAIC, hepatic arterial infusion chemotherapy; IFN, interferon; LFP, low dose 5-fluorouracil (5-FU) plus cisplatin; ORR, objective response rate; PVTT, portal vein tumor thrombus; s.C, subcutaneous.

RT

Since the liver is a very radiosensitive organ, administration of considerable doses of radiation to the liver leads to radiationinduced liver disease. Patients with HCC are complicated by a background of chronic liver disease. The presence of background cirrhosis leads to lowering of the tolerable radiation dose of the liver tissue. ${ }^{32,33}$ Therefore, it is difficult in principle to indicate radiotherapy for patients with poor hepatic function.

In recent years, the number of patients with HCC for whom radiation is indicated has increased. This is because intensive irradiation from multiple directions has enabled a decrease of the dose to normal tissues through the development of three-dimensional radiotherapy regimens, as well as advances in image-guided radiation technology to deal with respiratory fluctuation, allowing enhancement of the antitumor effect and decreasing adverse events. ${ }^{33}$

Nakazawa et al. ${ }^{34}$ (Table 3 ) retrospectively examined the outcomes of sorafenib therapy and RT for Vp4 HCC and reported that their analysis with propensity score matching detected a significantly longer survival time in the RT group compared to the sorafenib group. Decreased white blood cell count in one patient was the only adverse event of grade 3 or higher. Yu et al. ${ }^{35}$ (Table 3) reported that the outcomes of RT for $\mathrm{Vp} 3 / \mathrm{Vp} 4 \mathrm{HCC}$ were complete regression in $3.6 \%$, partial regression in $50.2 \%$, stable disease in $25.6 \%$, and an MST of 10.6 months, indicating the usefulness of RT.

In recent years, we also identified occasional reports involving proton beam therapy for HCC. Proton beams can form an energy peak (Bragg peak) deep inside the body, enabling strong irradiation of the target in the deep site while decreasing irradiation of non-tumor sites. Sugahara et al. ${ }^{36}$ (Table 3 ) reported that proton beam therapy for HCC with PVTT resulted in a 2 -year local control rate of $91 \%$ and a 2 -year survival rate of $48 \%$, showing good outcomes. Regarding adverse events, decreased blood cells were the only acute adverse event of grade 3 or higher, occurring in several patients, and no late adverse events of grade 3 or higher were seen.

Table 3. Radiotherapy for hepatocellular carcinoma with advanced portal vein tumor thrombus

\begin{tabular}{|c|c|c|c|c|}
\hline Author Ref & Treatment & Degree of PVTT; $n$ & $\begin{array}{l}\text { Median survival } \\
\text { time in months }\end{array}$ & Adverse event; $\mathrm{n}$ \\
\hline Nakazawa 34 & $\begin{array}{l}\text { Three-dimensional } \\
\text { conformal RT }\end{array}$ & $\begin{array}{l}\text { Vp3; } 19 \\
\text { Vp4; } 9\end{array}$ & 10.9 & $\begin{array}{l}\text { Gr3 or above } \\
\quad \text { Leukocytopenia; } 1\end{array}$ \\
\hline $\mathrm{Yu}^{35}$ & $\begin{array}{l}\text { Three-dimensional } \\
\text { conformal RT }\end{array}$ & $\begin{array}{l}\text { Hemiliver; } 150 \\
\text { Bilateral } \\
\text { hemiliver; } 4 \\
\text { Main; } 114 \\
\text { SMV; } 13\end{array}$ & 11.6 & $\begin{array}{l}\text { Gr3 or above } \\
\quad \text { Nausea; } 1 \\
\text { AST elevation; } 40 \\
\text { ALT elevation; } 15 \\
\text { ALP elevation; } 3 \\
\text { Clinical liver dysfunction; } 15 / 260\end{array}$ \\
\hline Sugahara ${ }^{36}$ & Proton-beam & $\begin{array}{l}\text { Branch; } 15 \\
\text { Trunk; } 20\end{array}$ & 22 & $\begin{array}{l}\text { Gr3 or above } \\
\quad \text { Leukocytopenia; } 1 \\
\text { Thrombocytopenia; } 1\end{array}$ \\
\hline
\end{tabular}

Abbreviations: ALP, alkaline phosphatase; ALT, alanine aminotransferase; AST, aspartate aminotransferase; Gr, grade; PVTT, portal vein tumor thrombus; SMV, superior mesenteric vein. 
Moriguchi M. et al: Non-operative treatments for HCC with PVTT

Table 4. Sorafenib for hepatocellular carcinoma with advanced portal vein tumor thrombus

\begin{tabular}{|c|c|c|c|c|c|}
\hline Author Ref & Treatment & Degree of PVTT; $n$ & MST, TTP in months & ORR, DCR; \% & Adverse event; \% or $\mathrm{n}$ \\
\hline Bruix $^{40}$ & Sorafenib & $\begin{array}{l}\text { MVI; } 108 \\
\text { (details; unclear) }\end{array}$ & MST; 8.1 & DCR; 38.9 & \\
\hline Jeong $^{41}$ & Sorafenib & $\begin{array}{l}\text { Vp3; } 6 \\
\text { Vp4; } 24\end{array}$ & $\begin{array}{l}\text { TTP; } 2.1 \\
\text { MST; } 3.1\end{array}$ & $\begin{array}{l}\text { ORR; } 10 \\
\text { DCR; } 40\end{array}$ & $\begin{array}{l}\text { Gr3 or above } \\
\text { Fatigue; } 10 \% \\
\text { HFSR; } 3.3 \% \\
\text { Liver dysfunction; } 3.3 \%\end{array}$ \\
\hline Song ${ }^{42}$ & Sorafenib & $\begin{array}{l}\text { Vp2; } 5 \\
\text { Vp3; } 16 \\
\text { Vp4; } 39\end{array}$ & $\begin{array}{l}\text { TTP; } 2.1 \\
\text { MST; } 5.5\end{array}$ & $\begin{array}{l}\text { ORR; } 13.3 \\
\text { DCR; } 45.0\end{array}$ & $\begin{array}{l}\text { Gr3 or above } \\
\text { HFSR; } 7 \\
\text { Rash; } 3 \\
\text { Diarrhea; } 13 \\
\text { Fatigue; } 8\end{array}$ \\
\hline
\end{tabular}

Abbreviations: DCR, disease control rate; Gr, grade; HFSR, hand-foot-skin reaction; MST, median survival time; MVI, macroscopic vascular invasion; ORR, objective response rate; PVTT, portal vein tumor thrombus; TTP, time to progression.

\section{Sorafenib}

Sorafenib is an oral multikinase inhibitor ${ }^{37}$ and its usefulness for advanced $\mathrm{HCC}$ has been demonstrated by two global phase III trials. ${ }^{38,39}$ Moreover, in the results of the subanalysis, the MST of patients with macroscopic vascular invasion was 4.9 and 8.1 months in the placebo and sorafenib arms (hazard ratio: 0.68 [0.49-0.93]), respectively, showing that sorafenib prolonged survival time significantly (Table 4). ${ }^{40}$ Therefore, sorafenib therapy is positioned as the standard therapy for HCC patients with PVTT who have Child-Pugh liver function class A. ${ }^{40}$

However, Jeong et al. ${ }^{41}$ (Table 4 ) reported that sorafenib therapy for $\mathrm{Vp} 3 / \mathrm{Vp} 4 \mathrm{HCC}$ had a response rate of $10 \%$,

Table 5. Combination therapy for hepatocellular carcinoma with advanced portal vein tumor thrombus

\begin{tabular}{|c|c|c|c|c|c|}
\hline Author Ref & Treatment & $\begin{array}{l}\text { Degree of PVTT; } \\
\mathrm{n}(\%)\end{array}$ & $\begin{array}{l}\text { Median } \\
\text { survival time } \\
\text { in months }\end{array}$ & $\begin{array}{l}\text { Evaluation; } \\
\% \text { or } n\end{array}$ & Adverse event; \% \\
\hline Chung $^{43}$ & c-TACE+RT & Main; 151 & 12 & ORR; $25.2 \%$ & 30-day mortality; $0.7 \%$ \\
\hline Yoon ${ }^{44}$ & $\mathrm{C}-\mathrm{TACE}+\mathrm{RT}$ & $\begin{array}{l}\text { Main or bilateral } \\
\text { PVTT; } 200 \\
(48.5 \%)\end{array}$ & 10.6 & $\begin{array}{l}\text { CR; } 3.6 \% \\
\text { ORR; } 27.9 \%\end{array}$ & $\begin{array}{l}\text { Gr3-4 hepatic toxicity; } 10 \% \\
\text { Gr2-3 gastroduodenal toxicity; } \\
3.6 \%\end{array}$ \\
\hline $\operatorname{Pan}^{45}$ & c-TACE+sorafenib & $\begin{array}{l}\text { Vp2; } 8 \\
\text { Vp3; } 23 \\
\text { Vp4; } 10\end{array}$ & 13 & $\begin{array}{l}\text { CR; } 1 \\
\text { PR; } 3 \\
\text { SD; } 34\end{array}$ & $\begin{array}{l}\text { Gr3 or above } \\
\text { HFSR; } 7.3 \% \\
\text { Myelosuppression; } 2.4 \% \\
\text { Hypertension; } 2.4 \%\end{array}$ \\
\hline Zhu $^{46}$ & c-TACE+sorafenib & $\begin{array}{l}\text { Main; } 10 \\
\text { First branch; } 19 \\
\text { Second or lower } \\
\text { branch; } 17\end{array}$ & 11.0 & $\begin{array}{l}\mathrm{PR} ; 13 \\
\mathrm{SD} ; 13\end{array}$ & $\begin{array}{l}\text { Gr3 or above } \\
\text { HFSR; } 11 \% \\
\text { Diarrhea; } 11 \% \\
\text { Hypertension; } 4 \% \\
\text { Gastrointestinal hemorrhage; } 9 \%\end{array}$ \\
\hline Chen ${ }^{47}$ & $\mathrm{RT}+$ sorafenib & $\begin{array}{l}\text { Unknown in } \\
\text { detail; } 24 \\
(40 \%)\end{array}$ & $\begin{array}{l}\text { 2-year } \\
\text { survival; } \\
32 \%\end{array}$ & ORR; $55 \%$ & $\begin{array}{l}\text { Gr3 or above } \\
\quad \text { hepatic toxicity; } 15 \%\end{array}$ \\
\hline Ikeda ${ }^{31}$ & $\begin{array}{l}\text { Sorafenib+HAIC } \\
\text { (cisplatin) }\end{array}$ & $\begin{array}{l}\text { Vp } 1 ; 4 \\
\text { Vp } 2 ; 9 \\
\text { Vp } 3 ; 14 \\
\text { Vp4; } 13\end{array}$ & 9.1 & & $\begin{array}{l}\text { * Myelosuppression, hyponatremia, } \\
\text { nausea and hiccups were more } \\
\text { frequent than in the sorafenib alone } \\
\text { treatment }\end{array}$ \\
\hline Fujino $^{48}$ & $\begin{array}{l}\text { 3D-CRT+HAIC } \\
\text { (low-dose 5FU and } \\
\text { cisplatin, 5FU with } \\
\text { IFN s.c.) }\end{array}$ & $\begin{array}{l}\text { Vp3; } 18 \\
\text { Vp4; } 23\end{array}$ & 12.1 & $\begin{array}{l}\text { CR; } 5 \% \\
\text { PR; } 24 \% \\
\text { SD; } 39 \%\end{array}$ & $\begin{array}{l}\text { G3 or above } \\
\text { Leukopenia; } 12.2 \% \\
\text { Thrombocytopenia; } 14.3 \% \\
\text { AST or ALT elevation; } 12.2 \% \\
\text { Bil elevation; } 14.3 \%\end{array}$ \\
\hline
\end{tabular}

Abbreviations: 5-FU, 5-fuluorouracil; ALT, alanine aminotransferase; AST, aspartate aminotransferase; Bil, bilirubin; CR, complete response; C-TACE, conventional transarterial chemoembolization; Gr, grade; HAIC, hepatic arterial infusion chemotherapy; HFSR, hand-foot-skin reaction; IFN, interferon; ORR, objective response rate; PR, partial response; PVTT, portal vein tumor thrombus; s.c., subcutaneous; SD, stable disease; RT, radiotherapy. 
Moriguchi M. et al: Non-operative treatments for HCC with PVTT

a disease control rate of $40 \%$, a median time to progression of 2.1 months, and an MST of 3.1 months, which are not satisfactory outcomes. In addition, Song et al. ${ }^{42}$ (Table 4) reported that the outcomes of sorafenib therapy for Vp2-4 HCC were a response rate of $13.3 \%$, a disease control rate of $44 \%$, a median time to progression of 2.1 months, and an MST of 5.5 months. Sorafenib is the sole non-operative standard treatment for HCC with macroscopic vascular invasion; however, its effect on Vp3/Vp4 HCC may be limited. Although there have been reports on the effect of sorafenib on HCC with PVTT, the studies did not feature sufficient numbers of patients; thus, more data must be accumulated.

\section{Combination treatment}

As mentioned above, various attempts have been made to treat HCC with PVTT, but the outcomes of monotherapies are not satisfactory. For that reason, combinations of various therapies have been attempted with the aim of outcome improvement.

Combinations of TACE and RT, ${ }^{43,44}$ TACE and sorafenib, 45,46 sorafenib and $\mathrm{RT}^{47}$ sorafenib and HAIC, ${ }^{31}$ HAIC and RT (Table 5), 48 and others have been reported. As Table 5 shows, moderately good results have been obtained, but the data remain insufficient. Further investigation with prospective trials is necessary.

\section{Future prospects}

With regard to non-operative treatments for $\mathrm{HCC}$ with advanced PVTT, not only improvement of monotherapies but also various measures including combinations of different therapies have been attempted. However, a satisfactory outcome has not been reached. Although occasionally some studies obtain promising results, they have insufficient data and require verification with a prospective trial.

Control of PVTT is likely to influence the prognosis of HCC with advanced PVTT. Because the standard therapy, sorafenib, produces a low response rate when administered as systemic chemotherapy, it appears preferable to combine it with local therapy (TACE, HAIC, RT, etc) with the expectation that local control will improve.

Regorafenib has recently been demonstrated to be effective for sorafenib-resistant HCC. ${ }^{49}$ Going forward, systemic chemotherapy with regorafenib is anticipated to be effective for HCC with advanced PVTT. In addition, systemic chemotherapy will likely require the development of agents with a high response rate against HCC with PVTT. We are awaiting the results of an ongoing phase III clinical trial of lenvatinib (NCT01761266 [E7080]), as well as from trials of immune checkpoint inhibitors (nivolumab [NCT02576509], pembrolizumab [NCT02702401; KEYNOTE-240], etc) that have completely different mechanisms than conventional anticancer agents.

\section{Conflict of interest}

Itoh $\mathrm{Y}$ received research grants from Esai Co., Ltd., Merck Sharp and Dohme Co., Ltd., Sumitomo Dainihon Pharma Co., Ltd., Nihon Kayaku Co., Ltd. and Bristol-Myers Squibb Company, and received lecture fees from Esai Co., Ltd., Merck Sharp and Dohme Co., Ltd., Sumitomo Dainihon Pharma Co., Ltd. and Bristol-Myers Squibb Company.
Moriguchi $M$ received a research grant from Merck Sharp and Dohme Co., Ltd.

\section{Author contributions}

Reviewed, designed and wrote the manuscript (MM), collected the data (MM, MF), revised the manuscript for important intellectual content (MM, YI).

\section{References}

[1] El-Serag HB, Rudolph KL. Hepatocellular carcinoma: epidemiology and molecular carcinogenesis. Gastroenterology 2007;132:2557-2576. doi: 10.1053/j.gastro.2007.04.061.

[2] Takizawa D, Kakizaki S, Sohara N, Sato K, Takagi H, Arai H, et al. Hepatocellular carcinoma with portal vein tumor thrombosis: clinical characteristics, prognosis, and patient survival analysis. Dig Dis Sci 2007;52:3290-3295. doi: 10.1007/s10620-007-9808-2.

[3] Lin DX, Zhang QY, Li X, Ye QW, Lin F, Li LL. An aggressive approach leads to improved survival in hepatocellular carcinoma patients with portal vein tumor thrombus. J Cancer Res Clin Oncol 2011;137:139-149. doi: 10. 1007/s00432-010-0868-x.

[4] Llovet JM, Bustamante J, Castells A, Vilana R, Ayuso Mdel C, Sala M, et al. Natural history of untreated nonsurgical hepatocellular carcinoma: rationale for the design and evaluation of therapeutic trials. Hepatology $1999 ; 29$ : 62-67. doi: 10.1002/hep.510290145.

[5] Minagawa M, Makuuchi M. Treatment of hepatocellular carcinoma accompanied by portal vein tumor thrombus. World J Gastroenterol 2006;12: 7561-7567. doi: 10.3748/wjg.v12.i47.7561.

[6] Schöniger-Hekele M, Müller C, Kutilek M, Oesterreicher C, Ferenci P, Gangl A. Hepatocellular carcinoma in Central Europe: prognostic features and survival. Gut 2001;48:103-109. doi: 10.1136/gut.48.1.103.

[7] Huang J, Deng Q, Wang Q, Li KY, Dai JH, Li N, et al. Exome sequencing of hepatitis B virus-associated hepatocellular carcinoma. Nat Genet 2012; 44:1117-1121. doi: 10.1038/ng.2391.

[8] Katagiri S, Yamamoto M. Multidisciplinary treatments for hepatocellular carcinoma with major portal vein tumor thrombus. Surg Today 2014;44: 219-226. doi: 10.1007/s00595-013-0585-6.

[9] Liver Cancer Study Group of Japan. The general rules for the clinical and pathological study of primary liver cancer, second edition. Tokyo: Kanehara \& Co., Ltd., 2003.

[10] Kokudo T, Hasegawa K, Matsuyama Y, Takayama T, Izumi N, Kadoya M, et al. Survival benefit of liver resection for hepatocellular carcinoma associated with portal vein invasion. J Hepatol 2016;65:938-943. doi: 10.1016/j. jhep.2016.05.044.

[11] Shuqun C, Mengchao W, Han C, Feng S, Jiahe Y, Guanghui D, et al. Tumor thrombus types influence the prognosis of hepatocellular carcinoma with the tumor thrombi in the portal vein. Hepatogastroenterology 2007;54: 499-502.

[12] Shi J, Lai EC, Li N, Guo WX, Xue J, Lau WY, et al. A new classification for hepatocellular carcinoma with portal vein tumor thrombus. J Hepatobiliary Pancreat Sci 2011;18:74-80. doi: 10.1007/s00534-010-0314-0.

[13] Yamada R, Sato M, Kawabata M, Nakatsuka H, Nakamura K, Takashima S. Hepatic artery embolization in 120 patients with unresectable hepatoma. Radiology 1983;148:397-401. doi: 10.1148/radiology.148.2.6306721.

[14] Chung GE, Lee JH, Kim HY, Hwang SY, Kim JS, Chung JW, et al. Transarterial chemoembolization can be safely performed in patients with hepatocellular carcinoma invading the main portal vein and may improve the overall survival. Radiology 2011;258:627-634. doi: 10.1148/radiol.10101058.

[15] Liu L, Zhang C, Zhao Y, Qi X, Chen H, Bai W, et al. Transarterial chemoembolization for the treatment of advanced hepatocellular carcinoma with portal vein tumor thrombosis: prognostic factors in a single-center study of 188 patients. Biomed Res Int 2014;2014:194278. doi: 10.1155/2014/194278.

[16] Niu ZJ, Ma YL, Kang P, Ou SQ, Meng ZB, Li ZK, et al. Transarterial chemoembolization compared with conservative treatment for advanced hepatocellular carcinoma with portal vein tumor thrombus: using a new classification. Med Oncol 2012;29:2992-2997. doi: 10.1007/s12032-0110145-0.

[17] Luo J, Guo RP, Lai EC, Zhang YJ, Lau WY, Chen MS, et al. Transarterial chemoembolization for unresectable hepatocellular carcinoma with portal vein tumor thrombosis: a prospective comparative study. Ann Surg Oncol 2011; 18:413-420. doi: 10.1245/s10434-010-1321-8.

[18] Chern MC, Chuang VP, Liang CT, Lin ZH, Kuo TM. Transcatheter arterial chemoembolization for advanced hepatocellular carcinoma with portal vein invasion: safety, efficacy, and prognostic factors. J Vasc Interv Radiol 2014; 25:32-40. doi: 10.1016/j.jvir.2013.10.013. 
[19] Tsochatzis EA, Fatourou E, O'Beirne J, Meyer T, Burroughs AK. Transarterial chemoembolization and bland embolization for hepatocellular carcinoma. World J Gastroenterol 2014;20:3069-3077. doi: 10.3748/wjg.v20.i12. 3069.

[20] Kalva SP, Pectasides M, Liu R, Rachamreddy N, Surakanti S, Yeddula K, et al. Safety and effectiveness of chemoembolization with drug-eluting beads for advanced-stage hepatocellular carcinoma. Cardiovasc Intervent Radio 2014;37:381-387. doi: 10.1007/s00270-013-0654-7.

[21] Sangro B, Carpanese L, Cianni R, Golfieri R, Gasparini D, Ezziddin S, et al. Survival after yttrium-90 resin microsphere radioembolization of hepatocellular carcinoma across Barcelona clinic liver cancer stages: a European evaluation. Hepatology 2011;54:868-878. doi: 10.1002/hep.24451.

[22] Memon K, Kulik L, Lewandowski RJ, Mulcahy MF, Benson AB, Ganger D, et al. Radioembolization for hepatocellular carcinoma with portal vein thrombosis: impact of liver function on systemic treatment options at disease progression. J Hepatol 2013;58:73-80. doi: 10.1016/j.jhep.2012.09.003.

[23] Mazzaferro V, Sposito C, Bhoori S, Romito R, Chiesa C, Morosi C, et al. Yttrium-90 radioembolization for intermediate-advanced hepatocellular carcinoma: a phase 2 study. Hepatology 2013;57:1826-1837. doi: 10. 1002/hep.26014.

[24] Salem R, Lewandowski RJ, Mulcahy MF, Riaz A, Ryu RK, Ibrahim S, et al. Radioembolization for hepatocellular carcinoma using Yttrium-90 microspheres: a comprehensive report of long-term outcomes. Gastroenterology 2010;138:52-64. doi: 10.1053/j.gastro.2009.09.006.

[25] Kulik LM, Carr BI, Mulcahy MF, Lewandowski RJ, Atassi B, Ryu RK, et al. Safety and efficacy of $90 \mathrm{Y}$ radiotherapy for hepatocellular carcinoma with and without portal vein thrombosis. Hepatology 2008;47:71-81. doi: 10 . 1002/hep. 21980

[26] Riaz A, Lewandowski RJ, Kulik LM, Mulcahy MF, Sato KT, Ryu RK, et al. Complications following radioembolization with yttrium-90 microspheres: a comprehensive literature review. J Vasc Interv Radiol 2009;20:1121-1130; quiz 1131. doi: 10.1016/j.jvir.2009.05.030.

[27] Ando E, Tanaka M, Yamashita F, Kuromatsu R, Yutani S, Fukumori K, et al. Hepatic arterial infusion chemotherapy for advanced hepatocellular carcinoma with portal vein tumor thrombosis: analysis of 48 cases. Cancer 2002;95:588-595. doi: 10.1002/cncr.10694.

[28] Obi S, Yoshida H, Toune R, Unuma T, Kanda M, Sato S, et al. Combination therapy of intraarterial 5-fluorouracil and systemic interferon-alpha for advanced hepatocellular carcinoma with portal venous invasion. Cancer 2006;106:1990-1997. doi: 10.1002/cncr.21832.

[29] Ikeda M, Okusaka T, Furuse J, Mitsunaga S, Ueno H, Yamaura H, et al. A multi-institutional phase II trial of hepatic arterial infusion chemotherapy with cisplatin for advanced hepatocellular carcinoma with portal vein tumor thrombosis. Cancer Chemother Pharmacol 2013;72:463-470. doi: 10. 1007/s00280-013-2222-x.

[30] Kudo M, Ueshima K, Yokosuka O, Obi S, Izumi N, Aikata H, et al. Prospective randomized controlled phase III trial comparing the efficacy of sorafenib versus sorafenib in combination with low-dose cisplatin/fluorouraci hepatic arterial infusion chemotherapy in patients with advanced hepatocellular carcinoma. J Hepatol 2016;64:S209. doi: 10.1016/S0168-8278 (16)00173-2.

[31] Ikeda M, Shimizu S, Sato T, Morimoto M, Kojima Y, Inaba Y, et al. Sorafenib plus hepatic arterial infusion chemotherapy with cisplatin versus sorafenib for advanced hepatocellular carcinoma: randomized phase II trial. Ann Oncol 2016;27:2090-2096. doi: 10.1093/annonc/mdw323.

[32] Cheng JC, Wu JK, Lee PC, Liu HS, Jian JJ, Lin YM, et al. Biologic susceptibility of hepatocellular carcinoma patients treated with radiotherapy to radiationinduced liver disease. Int J Radiat Oncol Biol Phys 2004;60:1502-1509. doi: 10.1016/j.ijrobp.2004.05.048.

[33] Pan CC, Kavanagh BD, Dawson LA, Li XA, Das SK, Miften M, et al. Radiationassociated liver injury. Int J Radiat Oncol Biol Phys 2010;76:S94-S100. doi: 10.1016/j.jijrobp.2009.06.092.

[34] Nakazawa T, Hidaka H, Shibuya A, Okuwaki $Y$, Tanaka $Y$, Takada J, et al. Overall survival in response to sorafenib versus radiotherapy in unresectable hepatocellular carcinoma with major portal vein tumor thrombosis: propensity score analysis. BMC Gastroenterol 2014;14:84. doi: 10.1186/1471230X-14-84.

[35] Yu JI, Park HC, Lim DH, Park W, Yoo BC, Paik SW, et al. Prognostic index for portal vein tumor thrombosis in patients with hepatocellular carcinoma treated with radiation therapy. J Korean Med Sci 2011;26:1014-1022. doi: 10.3346/jkms.2011.26.8.1014.

[36] Sugahara S, Nakayama H, Fukuda K, Mizumoto M, Tokita M, Abei M, et al. Proton-beam therapy for hepatocellular carcinoma associated with portal vein tumor thrombosis. Strahlenther Onkol 2009;185:782-788. doi: 10. 1007/s00066-009-2020-x.

[37] Wilhelm SM, Carter C, Tang L, Wilkie D, McNabola A, Rong $\mathrm{H}$, et al. BAY 43-9006 exhibits broad spectrum oral antitumor activity and targets the RAF/MEK/ERK pathway and receptor tyrosine kinases involved in tumor progression and angiogenesis. Cancer Res 2004;64:7099-7109. doi: 10 . 1158/0008-5472.CAN-04-1443.

[38] Llovet JM, Ricci S, Mazzaferro V, Hilgard P, Gane E, Blanc JF, et al. Sorafenib in advanced hepatocellular carcinoma. N Engl J Med 2008;359:378-390. doi: 10.1056/NEJMoa0708857.

[39] Cheng AL, Kang YK, Chen Z, Tsao C], Qin S, Kim JS, et al. Efficacy and safety of sorafenib in patients in the Asia-Pacific region with advanced hepatocellular carcinoma: a phase III randomised, double-blind, placebocontrolled trial. Lancet Oncol 2009;10:25-34. doi: 10.1016/S1470-2045 (08)70285-7.

[40] Bruix J, Raoul JL, Sherman M, Mazzaferro V, Bolondi L, Craxi A, et al. Efficacy and safety of sorafenib in patients with advanced hepatocellular carcinoma: subanalyses of a phase III trial. J Hepatol 2012;57:821-829. doi: 10.1016/j. jhep.2012.06.014.

[41] Jeong SW, Jang JY, Shim KY, Lee SH, Kim SG, Cha SW, et al. Practical effect of sorafenib monotherapy on advanced hepatocellular carcinoma and portal vein tumor thrombosis. Gut Liver 2013;7:696-703. doi: 10.5009/gnl. 2013.7.6.696.

[42] Song DS, Song MJ, Bae SH, Chung WJ, Jang JY, Kim YS, et al. A comparative study between sorafenib and hepatic arterial infusion chemotherapy for advanced hepatocellular carcinoma with portal vein tumor thrombosis. J Gastroenterol 2015;50:445-454. doi: 10.1007/s00535-014-0978-3.

[43] Chung SR, Kim JH, Yoon HK, Ko GY, Gwon DI, Shin JH, et al. Combined cisplatin-based chemoembolization and radiation therapy for hepatocellular carcinoma invading the main portal vein. J Vasc Interv Radiol 2015;26: 1130-1138. doi: 10.1016/j.jvir.2015.05.006.

[44] Yoon SM, Lim YS, Won HJ, Kim JH, Kim KM, Lee HC, et al. Radiotherapy plus transarterial chemoembolization for hepatocellular carcinoma invading the portal vein: long-term patient outcomes. Int J Radiat Oncol Biol Phys 2012; 82:2004-2011. doi: 10.1016/j.ijrobp.2011.03.019.

[45] Pan T, Li XS, Xie QK, Wang JP, Li W, Wu PH, et al. Safety and efficacy of transarterial chemoembolization plus sorafenib for hepatocellular carcinoma with portal venous tumour thrombus. Clin Radiol 2014;69:e553-e561. doi: 10.1016/j.crad.2014.09.007.

[46] Zhu K, Chen J, Lai L, Meng X, Zhou B, Huang W, et al. Hepatocellular carcinoma with portal vein tumor thrombus: treatment with transarterial chemoembolization combined with sorafenib-a retrospective controlled study. Radiology 2014;272:284-293. doi: 10.1148/radiol.14131946.

[47] Chen SW, Lin LC, Kuo YC, Liang JA, Kuo CC, Chiou JF. Phase 2 study of combined sorafenib and radiation therapy in patients with advanced hepatocellular carcinoma. Int J Radiat Oncol Biol Phys 2014;88:1041-1047. doi: 10.1016/j.ijrobp.2014.01.017.

[48] Fujino H, Kimura T, Aikata H, Miyaki D, Kawaoka T, Kan H, et al. Role of 3-D conformal radiotherapy for major portal vein tumor thrombosis combined with hepatic arterial infusion chemotherapy for advanced hepatocellular carcinoma. Hepatol Res 2015;45:607-617. doi: 10.1111/hepr.12392.

[49] Bruix J, Qin S, Merle P, Granito A, Huang YH, Bodoky G, et al. Regorafenib for patients with hepatocellular carcinoma who progressed on sorafenib treatment (RESORCE): a randomised, double-blind, placebo-controlled, phase 3 trial. Lancet 2017;389:56-66. doi: 10.1016/S0140-6736(16)32453-9. 